\title{
History and prospects of abrasives development
}

\author{
Historia i perspektywy rozwoju ścierniw
}

\section{CZESŁAW NIŻANKOWSKI *}

DOI: https://doi.org/10.17814/mechanik.2017.11.163

\begin{abstract}
Division and classification of abrasives development periods is discussed. Abrasives of natural origin and hard and super hard synthetic abrasive currently used in the industry, are presented. The prospects of the appearance of ultra-hard abrasives in the form of hexagonal lonsdaleite and metallic hydrogen, are indicated.

KEYWORDS: natural abrasives, synthetic abrasives, development
\end{abstract}

\section{History of abrasive development}

Based on the results of archaeological research and the analysis of written sources, it can be stated that man began to use abrasive materials at least a dozen thousand years BC. Thus, already in the younger Palaeolithic using abrasive machining, not only spearheads and ax blades, but even sculptures of people and animals were produced. A particularly interesting example are the female figures in carved and polished tusks of mammoths.

Most of the abrasive was quartz sand, crushed crustaceans and sea mussels, as well as crushed pumice (fig. 1a). Attempts to produce a synthetic abrasive of alumina clay, grated animal bones and fat, this mixture was fired, and thus obtained material with a hardness of flint stone (excavations in Dolní Věstonice, Moravian - 17000 years BC). An interesting archeology is that in many clods, such material remained fingerprints, which do not differ from the fingerprints of modern human [8].

Written Chinese sources say that nearly 5000 years BC, a man held in high esteem crushed rock with abrasive corundum, the position of which recognizes the natural inclusions of ruby red. While Egyptian sources indicate that 3500 years $B C$ in the state of the pharaohs, natural diamonds were used as abrasive grains, then called amodeus, and for polishing - finely ground nut shells [1, 2].

A significant event in the period of application of abrasives of natural origin was discovered 900 years BC on the Greek island of Naxos so-called naxos deposits, fine-grained corundum or natural impure quartz, hematite and grenade. The importance of the discovery proves the complete exploitation of these deposits over the next millennium and the start of an intensive search of similar deposits in other regions of the world. The search was a success, as the nearby Smyrgla (now Turkey) found a huge emery deposit the name of the town was used this time (fig. 1b). The first period of natural abrasion exploitation was started almost 20,000 years ago.

\footnotetext{
* Prof. dr hab. inż. Czesław Niżankowski (nizan@mech.pk.edu.pl) - Politechnika Krakowska
}

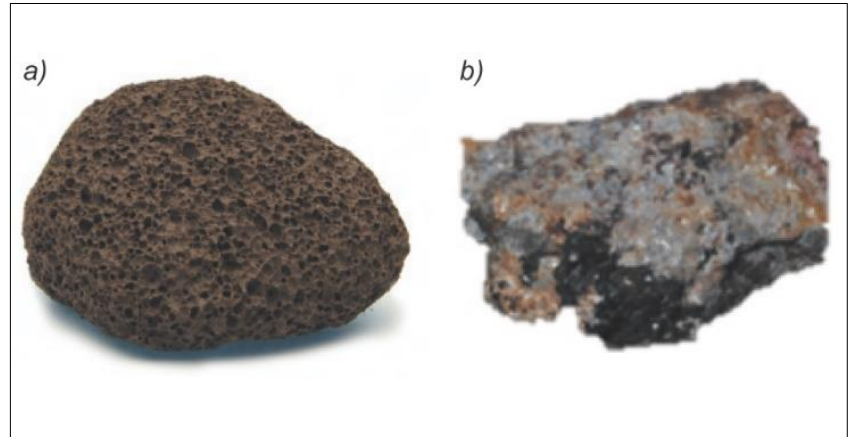

Fig. 1. Lumps of: a) natural pumice and b) emery [3, 4]

The second period of development of abrasive and abrasive tools began at the end of the 19th century when France first synthesized silicon carbide (Despretz 1848) and developed an industrial method for its manufacture (Acheson 1891) (fig. 2a). The subsequent years were almost exponential development of synthetic hard, melted abrasives and abrasives produced from them.

Hall and Higgins' research work, completed in 1900, enabled the start of the production of plain boride electrolyte, and Jeppson and Saunders' work - finished 10 years later started the production of white electrolyte alumina from technical alumina. In 1925. It was created spherical corundum, called follicular. Several years after reaching reported the first successful synthesis of boron carbide (Ridgway 1934) and started on the industrial scale production of mono-corundum abrasives [1]. In the 60 's, production of a wide range of modified electro-corundum: chromium, zirconium, titanium and titanium-zirconium was started (fig. $2 b$ ). All of these melted hard abrasives today are used in industry for the manufacture of various kinds of bulk and bonded abrasive tools and loose abrasives.
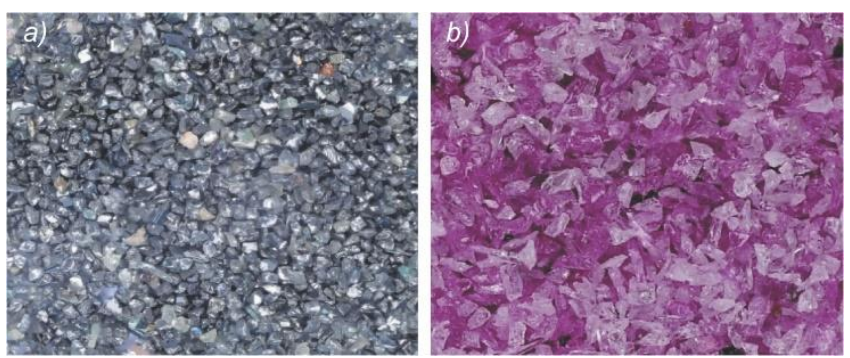

Fig. 2. Abrasives made of: a) black silicon carbide, $b$ ) chrome noble electro-corundum

The third period of abrasive development began between 1953 and 1955, when independently of each other, three teams of scientists from ASEA in Sweden, General Electric 
Company in the USA and De Beers in South Africa, received a synthetic diamond through an allotropic transformation of graphite in the presence of catalysts under heavy conditions of pressure $(4.5 \div 7.7 \mathrm{GPa})$ and high temperature $(1600 \div 1900$ K) [5]. This period lasts to this day. There have been developed 24 techniques for obtaining diamond abrasives under both static and dynamic conditions using different precursors (fig. 3a). The most original techniques include the production of synthetic diamonds from fullerenes, cane and charred bodies of humans or animals.

In the same period, in 1957, Wentorf developed a technology for the production of regular boron nitride from a hexagonal variety of this compound. The synthesis was also performed under high pressure conditions $(6.5 \div 9 \mathrm{GPa})$ and high temperatures $(1700 \div 2200 \mathrm{~K})$ depending on the catalysts used [6]. There are currently known 12 techniques for obtaining this super-hard (although resiliently synthetic diamond) abrasive (fig. $3 b$ )

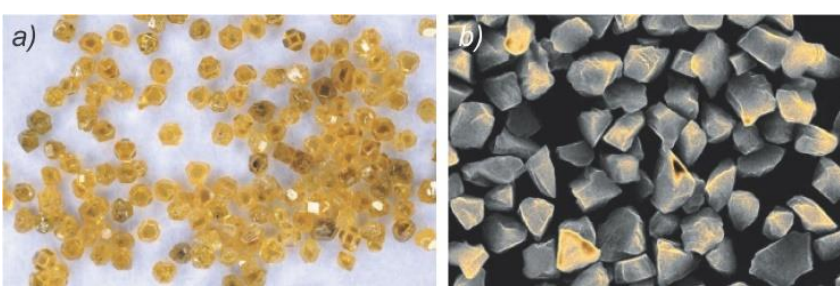

Fig. 3. Super-hard abrasives: a) synthetic diamond and b) regula boron nitride [7]

The high energy consumption of the abrasive products developed in the second and third periods of their development produced at the end of the 1960s preconditions for the replacement of melting processes of starting materials and high-temperature synthesis of sintering powders. This gave rise to the fourth period of development of abrasives and abrasive tools. Typical abrasives of this period are: polycrystalline sintered diamond, polycrystalline sintered regular boron nitride and polycrystalline sintered corundum. An interesting technology of the latter are large size abrasive grit (grain number $8 \div 24$ ), thus it is particularly useful in the preparation of large-size grinding wheel for high-press HPG grinding and sanding.
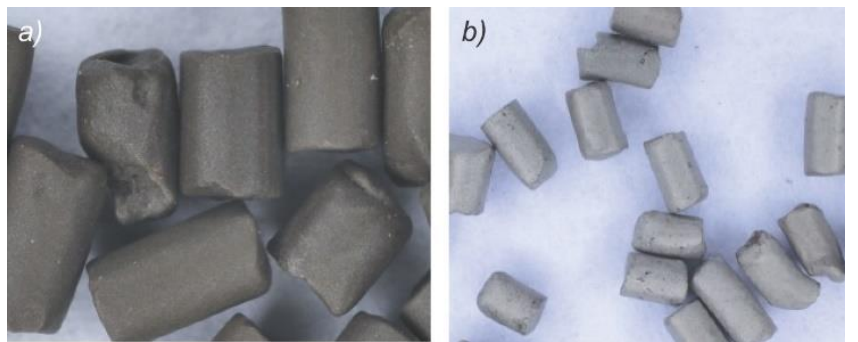

Fig. 4. Sintered abrasives: a) common sintered corundum and $b$ ) zirconium sintered corundum

With the possibility of producing abrasive powders by synthesis or mechanical grinding and sieving $(1 \div 10 \mu \mathrm{m})$, modern methods of further miniaturization of powders for sintering were started.
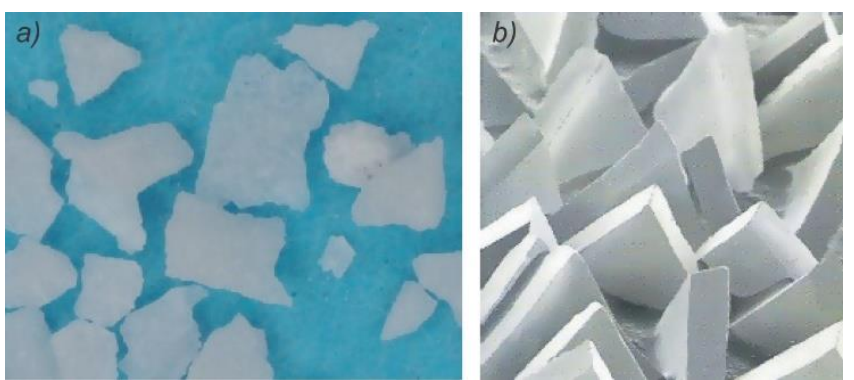

Fig. 5. Microcrystalline abrasives: a) Cubitron, b) Cubitron II [14]
The breakthrough in the history of abrasive development was in 1981, when $3 \mathrm{M}$ researchers developed a technology for the production of corundum abrasives using the sol-gel method. The process of manufacturing the Cubitron $®$ microcrystalline sintered corundum was a mystery until 1985, and the abrasives and abrasive tools produced by it were covered by the COCOM ban on exports to the postcommunist countries until 1992 (fig. 5a).

Currently, microcrystalline sintered corundum is widely used in both bonded and loose abrasive tools, but usually in the form of a noble corundum mixture. Due to the very small crystallites $(0.4 \div 1 \mu \mathrm{m}), \alpha-\mathrm{Al}_{2} \mathrm{O}_{3}$ sintered to each other in each abrasive grain of Cubitron ${ }^{\circledR}$ features a great selfsharpening characteristic, while at the same time low resistance of the proper micro-grinding process, and made with its abrasive tools distinguished by durability and vitality. Microcrystalline sintered corundum began the $\mathrm{V}$ period of abrasives development. It has also proved very susceptible to the formation of various geometrical masses, often with different proportions of dimensions (fig. 6a), and even changes in the position and shape of crystallites in the aggregate matrix of abrasive grains (fig. 6b).
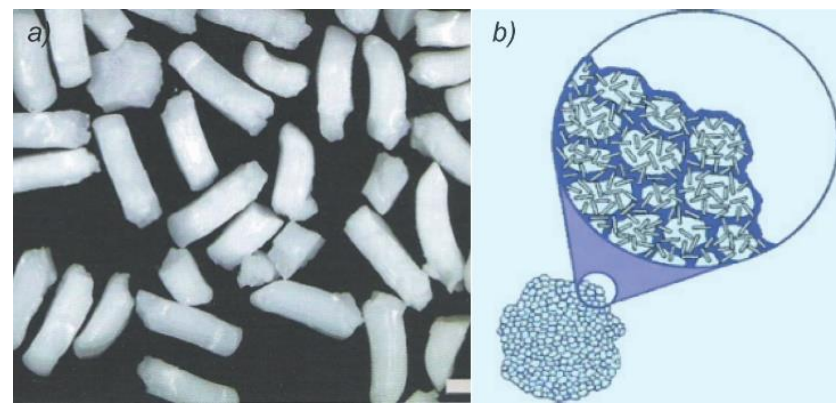

Fig. 6. Microcrystalline abrasives: a) TG and b) Cubitron 321TM [8]

Further development of the microcrystalline sintered corundum resulted in 3M's thin-walled abrasive in the form of straight prisms with an equilateral triangle base and a commercial name Cubitron $\|^{\mathrm{TM}}$, produced by microreplication (fig. $5 b$ ).

An intensive research on the possibility of obtaining new abrasive with improved operational properties led to the creation in 2007-2008 the new nano-crystalline $(10 \div 50 \mathrm{~nm})$ abrasive of sintered aluminum oxynitride in the form of $\alpha-$ $\mathrm{Al}_{\mathrm{x}} \mathrm{O}_{\mathrm{y}} \mathrm{N}_{\mathrm{z}}$ (abbreviated ALON) under the trade name Abral ${ }^{\mathrm{TM}}$ (fig. 7a) and nano-crystalline sintered corundum with market designation $\mathrm{NQ}^{\mathrm{TM}}$ (Nano Quantum) (fig. 7b). The creators of these abrasives were respectively Rappold Winterthur and Norton-Saint-Gobain Abrasives. Thus, in the first decade of the twentieth century, the $\mathrm{VI}$ period of abrasives development began.
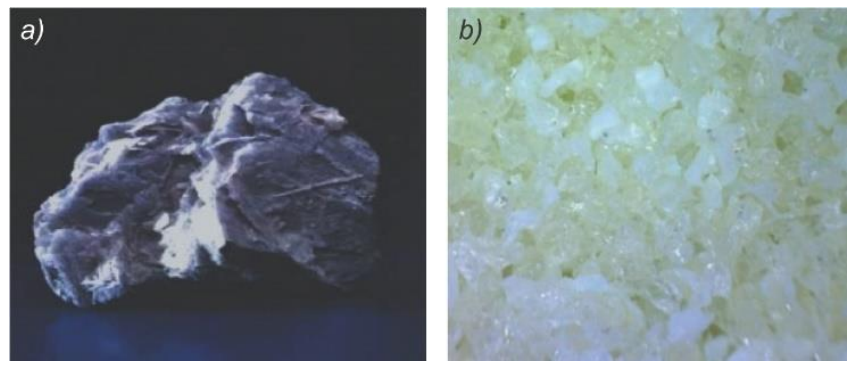

Fig. 7. Nano-crystalline abrasives: a) Abral and b) Nano Quantum [9]

\section{Perspectives of further development of abrasives}

Today's and forecasted state of the science and technology in abrasive machining requires the manufacture of new abrasives and abrasive tools that will offer a wide range of high performance, accuracy, WW-PO quality and manufacturing flexibility. This trend is inextricably linked with 
the use of increasingly new materials in the construction of products with unprecedented properties and with new techniques and means of processing.

According to the author, the next phase of abrasive development (VII) began in 2011, when the UK, using lowpressure targeted diamond synthesis under CVD conditions, produced abrasive in a form of long nano-crystalline diamond with high axially oriented grains [10]. The appearance of the NCLD diamond does not differ from that of a well-known LD diamond produced by PVD over a 20 year period, but it is significantly better in a view of its density, durability, viability and speed of spatial orientation in a toroidal electromagnetic field (fig. 8).
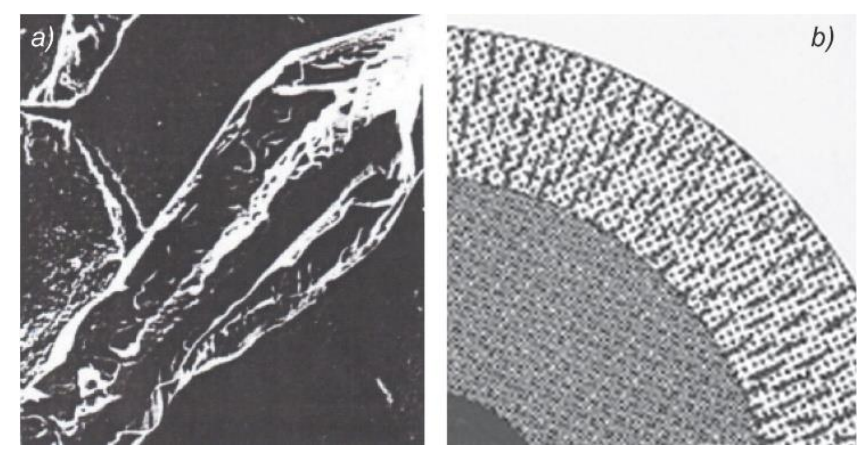

Fig. 8. Abrasive grain of long diamond (coniferous) NCLD (source Unicorn Industries Ltd. UK Companies)

An important step in the development of abrasives with a hardness greater than that of diamond has been the work of Prof. Zicheng Lord with Jiao Tong University in Shanghai. In 2014, New Scientist announced the possibility of producing an ultra-hard boron nitride (WBT), with hardness $18 \%$ higher than the hardness of natural diamond, and ultra-hard diamond polar with hexagonal symmetry, known as lonsdaleite and characterized by hardness $58 \%$ higher than the hardness of natural diamond. In December 2016, the team of Prof. Zicheng obtained the first small specimen (5 $\mathrm{mg}$ ) of clear brown-yellow lonsdaleite, using the phenomenon of shock-metamorphism of a pure graphite (fig. 9a [11]).
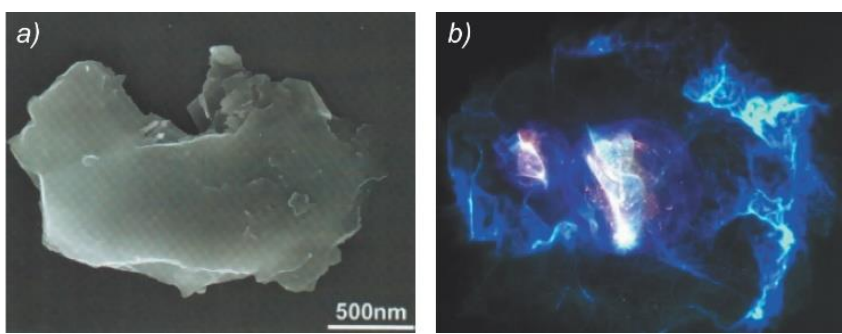

Fig. 9. Lonsdaleite abrasive grain (a) and sample of metallic hydrogen $(b)[12,13]$

A breakthrough in the development of abrasives (and not only) may be the result of an experiment carried out in January 2017 at Harvard University by a team of researchers working under the guidance of Prof. Isaac Silvera. It consisted of getting a metallic hydrogen that is 3-times harder than the natural diamond. It was prepared in a specially designed diamond chamber, at a pressure of $495 \mathrm{GPa}$ and at a temperature of $5.5 \mathrm{~K}$. This microscopic sample (fig. 9b) shows superconducting properties. Further testing is required to determine the metastable phases at ambient temperatures and finally - for micro-milling.

\section{Conclusions}

The history of abrasives can be divided into 6 periods:

- period I - use of natural abrasives,

- period II - application of melted hard abrasives,

- period III - use of super-hard abrasives,
- period IV - use of freely sintered abrasives,

- period V-use of microcrystalline abrasives,

- period VI- use of nano-crystalline abrasives.

Each subsequent development period of the abrasive was shorter. Today is the seventh period of abrasive development, named by the author as the period of ultra-hard abrasives. The possible use of ultra-hard abrasives made of lonsdaleite and metallic hydrogen in industrial practice requires, however, further research, thorough economic and technical analysis of such activities and development of new composite binders.

\section{REFERENCES}

1. Woźniak K. „Materiały ścierne - wytwarzanie i właściwości”. Warszawa: Wydawnictwa Naukowo-Techniczne, 1998.

2. Niżankowski Cz. „Technologia i eksploatacja ściernic z korundów spiekanych stosowanych w procesach szlifowania płaszczyzn". Kraków: Wydawnictwo Politechniki Krakowskiej, 2013.

3. (21.09.2017)

4 https://upload.wikimedia.org/wikipedia/commons/thumb/f/fb/ Schmirgel.009607.png/220px-Schmirgel.009607.png/ (21.09.2017). 5. Jaworska L. „Diament - otrzymywanie i zastosowanie w obróbce skrawaniem". Warszawa: Wydawnictwa Naukowo-Techniczne, 2007.

6. Olszyna A. „Ceramika supertwarda”. Warszawa: Oficyna Wydawnicza Politechniki Warszawskiej, 2001.

7. https://cdn6.bigcommerce.com/sshhk5/product_images/up loaded_images/diamond-powder.jpg?t=1461921944/ (21.09.2017).

8. Poradnik firmy Rappold - Winterthur, Hamburg 2010.

9. Nadolny $K$. „Nowa generacja ziaren ściernych z ALON zwiększająca efektywność szlifowania”. Mechanik. 8-9 (2012): page 670 .

10. Koizumi S., Nebel C.E., Nesladek M. „Physics and Applications of CVD Diamond". Weinheim: Wiley-VCH Verlag GmBH \& Co. KGaA, 2008.

11. http://dzienniknaukowy.pl/nowe-technologie/stworzonolonsdaleit-diament-twardszy-od-diamentu/ (dostęp: 10.08.2017).

12. „Lonsdaleit z meteorytów”. Świat Nauki. X 2010.

13. https://pl.sputniknews.com/swiat/201701284708591-Harvardwodor-metaliczny/ (10.08.2017).

14. Prospekty narzędziowe firmy 3M, USA 2014. 